\title{
Effect of Educational Guideline on Student Nurse Knowledge and Attitude Regarding Women Reproductive Rights
}

\author{
Fatma Kamal Ashry 1, Assist.Prof. Inaam Hasan Abd Elaty², Prof. Kamilia Ragab Abo \\ Shabana ${ }^{3}$, Dr.Maha Ramdan Ali ${ }^{2}$
}

Faculty of Nursing, Port Said University, Egypt ${ }^{1,2}$, Faculty of Nursing, Ain Shams

University, Egypt ${ }^{3}$

\begin{abstract}
Background: Women reproductive rights is nursing concern which is considered vital importance and one that has wide spread implications on health, wellbeing and development of the entire population. Reproductive health problems are leading cause of women's ill health and death worldwide.Aim: Evaluate the effect of educational guideline on student nurse knowledge and attitude regarding women reproductive rights. Design: A quasi-experimental research design. Sample: 83 female nursing students in the third and fourth academic year, purposive sample. Tools of data collection: Structured Interviewing, and women reproductive rights attitude assessment scale Results: A statistically significant improvement was observed among studied sample knowledge pre intervention compared to post intervention, significant improvement was observed among studied sample attitude pre intervention compared to post intervention, and the majority was satisfied with application of educational sessions regarding women rights. The study conclusion that there were statistically significant changes immediately following the introduction of the program and throughout the follow-up process regarding the analyzed sample awareness and perceptions relating to reproductive rights of women. Recommendation: the present recommended an educational guideline was suggested to be replicated in another setting and on another sampling.
\end{abstract}

Keywords: Attitude, educational guideline, reproductive rights. 


\section{INTRODUCTION}

Reproductive health care is defined as the constellation of methods, techniques and services, which contribute to reproductive health and well-being by preventing and resolving reproductive health problems. It also includes sexual wellbeing, the intent of which is to improve life and personal relationships and not merely reproductive and sexually transmitted disease therapy and treatment (World Health Organization, 2016).

In fact, reproductive rights are a relatively new concept and include the rights and freedoms of reproduction and reproductive health. Reproductive rights rest on the acceptance of the fundamental right of all women and men to freely and reasonably determine their children's number, spacing and timing and to have the knowledge and means to do so, and the right to attain the highest standard of sexual and reproductive health. Also, include the right of all to make decisions concerning reproduction free of discrimination (Maleshina, 2020).

Also, reproductive rights include the right to legal and safe abortion, the right to control independence from coerced sterilization and contraception, the right to access good quality reproductive healthcare, the right to education with a view to making free and educated reproductive choices. Reproductive rights may also include the right to receive education on aspects of sexuality related diseases, and defense against genderbased practices such as female genital mutilation (Turshen, 2020).

Nurse as a direct care provider must assess mother health through initial assessment by obtaining complete history, included family history, medical history, obstetric and gynecological history finally assess mother concept and misconception and her complains to identify her problem. Nursing intervention according to mother's reproductive needs, utilizing best evidence research as a base for her competent mother daily care respecting women culture, tradition women rights and ethical issues. Screening is the first step in early intervention, identifying emotional and behavioral issues and providing assistance at an early and successful stage; if problems are detected, further diagnosis and assessment will assess the appropriate care and services needed. Askew, Khosla, et al., (2016)

Proper and comprehensive nursing interventions are required to promote healthy development in the reproductive health and rights of adolescents and to prevent health 
problems or problem behaviors (primary prevention level), and to respond to them when and when they occur (secondary intervention level), and steps to reduce and minimize their vulnerability (tertiary stage of prevention). These include: knowledge and skills; a safe and supportive environment; and health and counseling services that are effective and affordable Ross, (2019).

\section{Significance of the Study:}

Building understanding of educating female nursing students about the problems they face will help them to mature in a healthy and fulfilling way, which is the best investment a society can make for its future. Also, organizing needs and problems will provide guide lines for the importing of health education to female nursing students. The nurses as a counselor and health educators have an effective role for providing, promoting and improving reproductive health and woman's right. Therefore, this study will be applied to enhance nursing student's knowledge and utilization of health services about woman rights in reproductive health.

\section{Aim:}

Assess the effect of educational guideline on student nurse knowledge and attitude regarding women reproductive rights.

\section{Research hypothesis:}

There is no effect of the women reproductive rights educational guideline on the students nurse knowledge and attitude

There are a significant difference between before and after score nurse students' knowledge and attitude.

\section{Subjects and method}

\section{Setting:}

The study was conducted at faculty of Nursing at Port Said University.

\section{Study design:}

A quasi-experimental research was applied in this study. 


\section{Subject}

\section{Sample size:}

The sample size was 92 female nursing students in the third and fourth academic year were selected in this study, and 8 student nurse was excluded due to their participation in pilot study.

Purposive sample was obtained from the previous mentioned setting.

\section{Inclusion criteria of sample:}

1- Female students

2- Third and fourth academic year

3- Age ranges between 18-22 years

4- Unmarried female student

\section{Exclusion criteria of sample:}

1- Males students

\section{Tools of data collections:}

The researcher constructed three tools after reviewing related literature. They were Structured Interview Questionnaire, and Women reproductive rights attitude assessment scale.

Tool (I): Structured Interview:

It included two main sections:

First Part: This part created by researcher after reviewing related literature Ibrahim, (2010) to assess personal characteristics of student such as ", "residence, order of student in the family, and number of teenager family member.

Second Part: pre post test: it consisted of fifteen MCQ questions created by researcher after reviewing related literature Adinew, Worku, \& Mengesha, (2013) \& Bhattarai, \& 
Dhakal, (2015) to assess student nurse's knowledge regards women reproductive rights

Scoring system:

A score of 2 was given to the correct and complete answer. A score 1 for the correct but incomplete answer, and a score of 0 for the wrong or when the student answered: "she does not know." The total knowledge scores were classified into three levels: Poor knowledge $(<50 \%)$, acceptable $(50 \%$

to $<75 \%$ ), and high $(\geq 75 \%)$.

2. Tool (II): women reproductive rights attitude assessment scale

A three-point Likert-scale ranging from agree to neutral and disagree created by researcher after reviewing related literature Rajapaksa, Piercy, Salway S, \& Samarage, (2014)to assess the students' attitude towards women reproductive rights. It consisted of five statements to which the students were requested to react to one of the decisions. Which covered (female genital mutilation, reproductive health, family planning, marriage, pregnancy).

Scoring system:

A score of 3 was given to agree; a score of 2 for neutral; and a score of 1 for disagree. Each statement scored, and the aggregate attitude score classified into three levels: negative attitude $(<35 \%)$, neutral attitude $(35 \%-<60 \%)$, and positive attitude (> $60 \%)$.

\section{Tool validity}

All tools of data collections were developed and sent to seven specialized university experts Prof in the field of study according to their comments, modifications were considered. Tools were submitted to three scholastic nursing specialists in the field of Maternity Nursing and Community Health Nursing to test content validity. Modifications were carried out according to the recommendations of the specialists.

\section{Reliability}

Tools validate for clarity, appropriateness, and completeness of the content. 
The reliability of the proposed tools was tested utilizing Cronbach's alpha. For the Preposttest, Cronbach's alpha of 0.81 showed a strong significant positive correlation between the items of the tool. While for the attitude assessment scale, it was 0.84 , which indicates accepted tools reliability.

\section{Ethical consideration:}

-Written informed consent was signed from each student in order to participate in the study.

-All approval documents were collected for officially conduct the study.

-Student dignity, privacy, confidentiality, culture, traditional and religious aspect were kept during and after data collection and analysis

Fieldwork: The study was implemented through three phases included the preparatory, implementation and evaluation phase.

\section{Phase I: preparation phase:}

The researcher had reviewed the current advanced national and international literature related to study topic, then prepared tools for data collection. All tools of data collection was utilized pre intervention then 8 weeks post intervention except satisfaction tool which was utilized eight weeks post intervention only and finally implement pilot study.

Phase II: implementation phase: Firstly. The researcher was interviewed one to three student /day according to sequence in academic year list and explain the aim of the study to obtain oral consent. Interview was conducted in a separate place to maintain confidentiality of the study.

Phase III: evaluation phase: this phase was utilized to evaluate effect of implemented educational guideline utilizing pretest format during pre and immediately post then 8 weeks post intervention.

\section{Data analysis}

Statistical analysis was done using SPSS 25 statistical software packages. Data were presented using descriptive statistics in the form of frequencies and percentages for 
qualitative variables, in addition to means and standard deviations for quantitative variables. Quantitative continuous data were compared using Student t-test in case of comparisons between two groups. Qualitative variables were compared using chisquare test. The collected data were organized, categorized, tabulated and analyzed by using the computer. Data entry was done using Epi-info computer software packager, while statistical analysis was done using statistical graphic, statistical software package, quality control was done at the stages of coding and data entry.

\section{Results:}

Table (1): illustrates the distribution of the studied sample according to their personal characteristics. The table reveals that the majority of sample were from urban, slightly less than half (47\%) of studied sample had first order in family, while three quarters of the studied sample $(69.9 \%)$ had teenager family member.

Table (2): shows the differences in studied sample knowledge related to women reproductive rights throughout the program intervention. high statistical significant difference in total score of studied sample knowledge was found between pre and post immediate and later 8 weeks program implementation were $(\mathrm{P}<0.001)$ in relation to women reproductive rights concept, right to privacy and family life, right to legal and safe abortion, right to menstrual health and protection from practices such as female genital mutilation, right to access good-quality reproductive healthcare, right to marry and found a family.

And also right to the highest attainable standard of health, right to benefit from scientific progress, right of women determine date of pregnancy after marriage, right to physical integrity, right to birth control; freedom from coerced sterilization and contraception, right to non-discrimination and equal treatment, right to information and education, right to life, right to receive education about sexually transmitted disease, and right to education and access in order to make free and informed reproductive choices.

Table (3): shows the differences in studied sample attitude related to reproductive health throughout the program intervention. Statistical significant difference in total score of studied sample attitude was found between pre and post immediate later 8 weeks program implementation were $(\mathrm{P}<0.05)$ in relation to female genital mutilation, reproductive health, family planning, marriage, and overall attitude. 
Table (4): shows the comparison between studied sample general characteristics and mean score of studied student's nurse's attitude related to women reproductive rights pre and post immediate and late 8 weeks program implementation. The only statistically significant difference was found between attitude of studied student's nurse's and their teenage family member $(\mathrm{P} \leq 0.05)$.

Table (5): shows the correlation between mean score of studied sample knowledge and their attitude throughout the program intervention. A high statistically significant positive correlation was found between studied sample knowledge and attitude immediately 8 weeks post intervention $\left(\mathrm{r}=0.856^{*}\right)$.

Table (1): Distribution of the studied sample according to their personal characteristics $(\mathrm{n}=92)$

\begin{tabular}{|l|l|l|}
\hline Personal characteristics & No. & \% \\
\hline Residence & & \\
\hline Urban & 80 & 96.4 \\
\hline Rural & 3 & 3.6 \\
\hline Order of the student in family & & \\
\hline First & 39 & 47.0 \\
\hline Second & 32 & 38.6 \\
\hline Third & 10 & 12.0 \\
\hline Fourth & 2 & 2.4 \\
\hline Teenage family member & & \\
\hline Yes & 58 & 69.9 \\
\hline No & 25 & \\
\hline
\end{tabular}


Table (2): Distribution of the studied sample knowledge related to women reproductive rights $(n=92)$

\begin{tabular}{|c|c|c|c|c|c|c|c|c|c|c|c|c|c|c|}
\hline \multirow{3}{*}{$\begin{array}{l}\text { Phases } \\
\text { Items }\end{array}$} & \multicolumn{4}{|c|}{$\begin{array}{l}\text { Pre intervention } \\
(\mathbf{n}=\mathbf{8 3})\end{array}$} & \multicolumn{4}{|c|}{$\begin{array}{l}\text { Immediate post } \\
\text { intervention }(n=83)\end{array}$} & & \multicolumn{4}{|c|}{$\begin{array}{l}\text { After } 8 \text { weeks post } \\
\text { intervention }(n=83)\end{array}$} & \multirow[t]{3}{*}{ p } \\
\hline & \multicolumn{2}{|c|}{\begin{tabular}{|l|} 
Correct \\
\end{tabular}} & \multicolumn{2}{|c|}{ Incorrect } & \multicolumn{2}{|c|}{ Correct } & \multicolumn{2}{|c|}{ Incorrect } & & \multicolumn{2}{|c|}{ Correct } & \multicolumn{2}{|c|}{ Incorrect } & \\
\hline & No. & $\%$ & No. & $\%$ & No. & $\%$ & No. & $\%$ & & No. & $\%$ & No. & $\%$ & \\
\hline $\begin{array}{l}\text { Women reproductive rights } \\
\text { concept }\end{array}$ & 2 & 2.4 & 81 & 97.6 & 83 & 100.0 & 0 & 0.0 & $<0.001$ & 83 & 100.0 & 0 & 0.0 & $<0.001^{*}$ \\
\hline $\begin{array}{l}\text { Right to Privacy and Family } \\
\text { Life }\end{array}$ & 13 & 15.7 & 70 & 84.3 & 83 & 100.0 & 0 & 0.0 & $<0.001^{\prime}$ & 83 & 100.0 & 0 & 0.0 & $<0.001^{*}$ \\
\hline right to legal and safe abortion & 33 & 39.8 & 50 & 60.2 & 83 & 100.0 & 0 & 0.0 & $<0.001^{\prime}$ & 83 & 100.0 & 0 & 0.0 & $<0.001^{*}$ \\
\hline $\begin{array}{l}\text { Right to menstrual health and } \\
\text { protection from practices such } \\
\text { as female genital mutilation }\end{array}$ & 26 & 31.3 & 57 & 68.7 & 83 & 100.0 & 0 & 0.0 & $<0.001$ & 83 & 100.0 & 0 & 0.0 & $<0.001^{*}$ \\
\hline $\begin{array}{l}\text { Right to access good-quality } \\
\text { reproductive healthcare }\end{array}$ & 13 & 15.7 & 70 & 84.3 & 83 & 100.0 & 0 & 0.0 & $<0.001^{*}$ & 83 & 100.0 & 0 & 0.0 & $<0.001^{*}$ \\
\hline $\begin{array}{l}\text { Right to Marry and Found a } \\
\text { Family }\end{array}$ & 7 & 8.4 & 76 & 91.6 & 83 & 100.0 & 0 & 0.0 & $<0.001^{*}$ & 83 & 100.0 & 0 & 0.0 & $<0.001^{*}$ \\
\hline $\begin{array}{l}\text { Right to the Highest Attainable } \\
\text { Standard of Health }\end{array}$ & 15 & 18.1 & 68 & 81.9 & 83 & 100.0 & 0 & 0.0 & $<0.001^{\prime}$ & 83 & 100.0 & 0 & 0.0 & $<0.001^{*}$ \\
\hline $\begin{array}{l}\text { Right to Benefit from Scientific } \\
\text { Progress }\end{array}$ & 17 & 20.5 & 66 & 79.5 & 83 & 100.0 & 0 & 0.0 & $<0.001^{\prime}$ & 83 & 100.0 & 0 & 0.0 & $<0.001^{*}$ \\
\hline Right to Physical Integrity & 14 & 16.9 & 69 & 83.1 & 83 & 100.0 & 0 & 0.0 & $<0.001^{\prime}$ & 83 & 100.0 & 0 & 0.0 & $<0.001^{*}$ \\
\hline $\begin{array}{l}\text { Right to birth control; freedom } \\
\text { from coerced sterilization and } \\
\text { contraception }\end{array}$ & & 39.8 & 50 & 60.2 & 83 & 100.0 & 0 & 0.0 & $<0.001^{\prime}$ & 83 & 100.0 & 0 & 0.0 & $<0.001^{*}$ \\
\hline $\begin{array}{l}\text { Right to non-discrimination and } \\
\text { equal treatment }\end{array}$ & 26 & 31.3 & 57 & 68.7 & 83 & 100.0 & 0 & 0.0 & $<0.001^{\circ}$ & 83 & 100.0 & 0 & 0.0 & $<0.001^{*}$ \\
\hline $\begin{array}{l}\text { Right to Information and } \\
\text { Education }\end{array}$ & 13 & 15.7 & 70 & 84.3 & 83 & 100.0 & 0 & 0.0 & $<0.001^{\prime}$ & 83 & 100.0 & 0 & 0.0 & $<0.001^{*}$ \\
\hline Right to Life & 7 & 8.4 & 76 & 91.6 & 83 & 100.0 & 0 & 0.0 & $<0.001^{\prime}$ & 83 & 100.0 & 0 & 0.0 & $<0.001^{*}$ \\
\hline $\begin{array}{lcr}\text { Right } & \text { to receive } & \text { education } \\
\text { about } & \text { sexually } & \text { transmitted } \\
\text { disease } & & \\
\end{array}$ & & 18.1 & 68 & 81.9 & 83 & 100.0 & 0 & 0.0 & $<0.001^{\prime}$ & 83 & 100.0 & 0 & 0.0 & $<0.001^{*}$ \\
\hline $\begin{array}{l}\text { Right to education and access } \\
\text { in order to make free and } \\
\text { informed reproductive choices }\end{array}$ & & 8.4 & 76 & 91.6 & 83 & 100.0 & 0 & 0.0 & $<0.001^{\prime}$ & 83 & 100.0 & 0 & 0.0 & $<0.001^{*}$ \\
\hline
\end{tabular}

p: p value for Friedman test using Post Hoc Test (Dunn's) for comparing between the studied periods

$\mathrm{p}_{1}$ : $\mathrm{p}$ value for Friedman test using Post Hoc Test (Dunn's) for comparing between pre and after 8 weeks period $\quad *$ : Statistically significant at $\mathrm{p} \leq 0.05$ 
Table (3): Distribution of the studied sample attitude pre and post intervention $(n=83)$

\begin{tabular}{|c|c|c|c|c|c|c|c|c|c|c|c|c|c|c|}
\hline \multirow{3}{*}{ Items } & \multicolumn{4}{|c|}{$\begin{array}{l}\text { Pre } \\
(\mathbf{n}=\mathbf{8 3})\end{array}$} & \multicolumn{4}{|c|}{$\begin{array}{l}\text { Immediate post } \\
\text { intervention }\end{array}$} & & \multicolumn{4}{|c|}{$\begin{array}{l}\text { After } 8 \text { weeks post } \\
\text { intervention } \\
(\mathbf{n}=\mathbf{8 3})\end{array}$} & \\
\hline & \multicolumn{2}{|c|}{ Agree } & \multicolumn{2}{|c|}{ Disagree } & \multicolumn{2}{|c|}{ Agree } & \multicolumn{2}{|c|}{ Disagree } & & \multicolumn{2}{|c|}{ Agree } & \multicolumn{2}{|c|}{ Disagree } & \\
\hline & No. & $\%$ & No. & $\%$ & No. & $\%$ & No. & $\%$ & & No. & $\%$ & No. & $\%$ & \\
\hline $\begin{array}{l}\text { Female genital } \\
\text { mutilation }\end{array}$ & 58 & 69.9 & 25 & 30.1 & 83 & 100.0 & 0 & 0.0 & $0.004^{*}$ & 83 & 100.0 & 0 & 0.0 & $0.004^{*}$ \\
\hline Reproductive health & 33 & 39.8 & 50 & 60.2 & 83 & 100.0 & 0 & 0.0 & $<0.001^{*}$ & 83 & 100.0 & 0 & 0.0 & $<0.001^{*}$ \\
\hline Family planning & 0 & 0.0 & 83 & 100.0 & 83 & 100.0 & 0 & 0.0 & $<0.001^{*}$ & 83 & 100.0 & 0 & 0.0 & $<0.001^{*}$ \\
\hline Marriage & 0 & 0.0 & 83 & 100.0 & 83 & 100.0 & 0 & 0.0 & $<0.001^{*}$ & 83 & 100.0 & 0 & 0.0 & $<0.001^{*}$ \\
\hline Pregnancy & 72 & 86.7 & 11 & 13.3 & 83 & 100.0 & 0 & 0.0 & 0.200 & 83 & 100.0 & 0 & 0.0 & 0.200 \\
\hline Overall attitude & 35 & 42.2 & 48 & 57.8 & 83 & 100.0 & 0 & 0.0 & $<0.001^{*}$ & 83 & 100.0 & 0 & 0.0 & $<0.001^{*}$ \\
\hline
\end{tabular}

Sig. bet. Periods was done using Post Hoc Test (LSD) for ANOVA with repeated measures

$\mathrm{p}_{1}$ : $\mathrm{p}$ value comparing between Pre intervention and immediate post intervention

$\mathrm{p}_{2}: \mathrm{p}$ value comparing between Pre intervention and After 8 weeks post intervention

*: Statistically significant at $\mathrm{p} \leq 0.05$ 
Table (4): Relation between studied sample general characteristics and their attitude related to women reproductive rights pre and post immediate and late 8 weeks program implementation

\begin{tabular}{|c|c|c|c|c|c|c|c|c|c|c|c|c|c|c|}
\hline \multirow{3}{*}{ Variable } & \multicolumn{4}{|c|}{ Pre intervention } & \multirow{3}{*}{$\chi^{2}$} & \multirow{3}{*}{$\mathbf{P}$} & \multicolumn{4}{|c|}{$\begin{array}{l}\text { Immediate } \\
\text { intervention }\end{array}$} & \multicolumn{4}{|c|}{$\begin{array}{l}\text { After } 8 \text { weeks pos } \\
\text { intervention }\end{array}$} \\
\hline & \multicolumn{2}{|c|}{$\begin{array}{l}\text { Agree } \\
\mathbf{n}=\mathbf{3 5}\end{array}$} & \multicolumn{2}{|c|}{$\begin{array}{l}\text { Disagree } \\
n=48\end{array}$} & & & \multicolumn{2}{|c|}{$\begin{array}{l}\text { Agree } \\
\mathrm{n}=\mathbf{8 3}\end{array}$} & \multicolumn{2}{|c|}{$\begin{array}{l}\text { Disagree } \\
\mathbf{n}=\mathbf{0}\end{array}$} & \multicolumn{2}{|c|}{$\begin{array}{l}\text { Agree } \\
\mathrm{n}=\mathbf{8 3}\end{array}$} & \multicolumn{2}{|c|}{$\begin{array}{l}\text { Disagree } \\
n=0\end{array}$} \\
\hline & & $\%$ & No & $\%$ & & & No & $\%$ & No & $\%$ & No & $\%$ & No & $\%$ \\
\hline Residence & & & & & & & & & & & & & & \\
\hline Urban & & 97.1 & 46 & 95.8 & \multirow{2}{*}{0.100} & \multirow{2}{*}{$\begin{array}{l}\mathrm{FE} p= \\
1.000\end{array}$} & 80 & 96.4 & - & - & 80 & 96.4 & - & - \\
\hline Rural & & 2.9 & 2 & 4.2 & & & 3 & 3.6 & - & - & 3 & 3.6 & - & F \\
\hline \multicolumn{15}{|c|}{ Order between family } \\
\hline First & & 40.0 & 25 & 52.1 & \multirow{4}{*}{1.797} & \multirow{4}{*}{$\begin{array}{l}{ }^{\mathrm{MC}} \mathrm{p}= \\
0.703\end{array}$} & 39 & 47.0 & - & - & 39 & 47.0 & - & - \\
\hline Second & & 45.7 & 16 & 33.3 & & & 32 & 38.6 & - & - & 32 & 38.6 & - & - \\
\hline Third & & 11.4 & 6 & 12.5 & & & 10 & 12.0 & - & - & 10 & 12.0 & - & - \\
\hline Fourth & & 2.9 & 1 & 2.1 & & & 2 & 2.4 & - & - & 2 & 2.4 & - & - \\
\hline $\begin{array}{l}\text { Teenage } \\
\text { member }\end{array}$ & & & & & & & & & & & & & & \\
\hline Yes & & 57.1 & 38 & 79.2 & & & 58 & 69.9 & - & - & 58 & 69.9 & - & - \\
\hline No & & 42.9 & 10 & 20.8 & & & 25 & 30.1 & - & - & 25 & 30.1 & - & - \\
\hline
\end{tabular}

\section{$\chi^{2}$ : Chi square test MC: Monte Carlo FE: Fisher Exact}

$\mathrm{p}: \mathrm{p}$ value for associating between different categories

*: Statistically significant at $\mathrm{p} \leq 0.05$ 
Table (5): Correlation between studied sample knowledge and their attitude regarding rights and reproductive health pre and post immediate and late 8 weeks program implementation $(\mathrm{n}=83)$

\begin{tabular}{|l|l|l|}
\hline \multicolumn{2}{|l|}{ Overall attitude } & \multicolumn{2}{|l|}{ P } \\
\cline { 2 - 3 } Overall knowledge & R & \\
\hline Pre intervention & & 0.229 \\
\hline Immediate post \&8 weeks & 0.133 & \\
\hline after intervention & & $<0.001^{*}$ \\
\hline
\end{tabular}

r: Pearson coefficient

*: Statistically significant at $\mathrm{p} \leq 0.05$

\section{DISCUSSION:}

The present study was aimed to evaluate the effect of educational guideline on student nurse knowledge and attitude regarding women reproductive rights. This was significantly achieved within the frame work of the present study research hypothesis student nurses who attended educational guideline that concern women reproductive rights has soon improved better on knowledge and their attitude than those who did not received. Because the present study finding has revealed that a significant improved among the studied sample knowledge concerning their right in reproductive health pre intervention compared to post intervention.

Regarding to nursing student's knowledge about right to privacy and family life the present study revealed that most of studied sample had incorrect knowledge during pre-intervention assessment and had improvement of knowledge during immediate post intervention and eight weeks post intervention. This finding was disagree with Shailaja, K., \& Johnson, M. E. C. (2007) who reported that most studied sample had incorrect knowledge regarding right to privacy and family life . also finding disagree with Center 
for Disease Control and Prevention, (2014) They stated that the most of respondent had correct knowledge regarding right to privacy and family life the rights to life and health. This may be due to Egyptian women don't have privacy in her life, and depend on father and husband in all decision in her life.

With regard to the awareness of nursing students regarding right to the highest attainable standard of health, this study shows that the majority of studied sample had incorrect knowledge pre-intervention and had improvement of knowledge in immediate post intervention and 8 weeks post intervention. This finding was agreed with Hallila, \& Al-Halabi, (2018) who revealed that most of the participants did not had correct knowledge regarding right to the highest attainable standard of health in Saudi Arabia. This may be due to spread of gender preference in Arabic society, especially regarding attainable to standard of health services.

Regarding to nursing student's knowledge about right to education and access in order to make free and informed reproductive choices. The present study finding revealed that majority of studied sample had incorrect knowledge during pre-intervention and had improvement of knowledge in immediate post intervention and eight weeks post intervention. This was agrees with Kaphle, Hancock \& Newman, (2013) who found that most of respondents had incorrect knowledge about right to education and access in order to make free and informed reproductive choices. This is may be due to lack of awareness regards availability and accessibility of reproductive choices.

Regarding to nursing student's knowledge about woman right to access goodquality reproductive healthcare. The finding of the present study reveals that most of studied sample were had incorrect knowledge during pre-intervention assessment and had improvement of knowledge during immediate post intervention and eight weeks post intervention. This was disagree with Elden, (2019) \& O'connell, \& Zampas, (2019) who reported that most of respondent had correct knowledge regard right to access goodquality reproductive healthcare. This is may be due to lack of awareness that sexual and reproductive health services are available, affordable, and appropriate and of good quality.

Regarding student nurse attitude toward marriage the majority of studied students had false opinion regarding select husband, premarital counseling important, and early teenager marriage This was disagree with Rashad, Khosla, et al., (2016) \& Shamekh, \& Ragheb, (2013) who reported that the majority of the study sample agrees 
that girls have the right to choose their prospective husband and marry. This is may be due to student belief that good behavior mean that respect and follow father decision regarding selection of suitable husband regarding father opinion regardless daughter opinion.

Regarding relation between studied nurses' personal characteristics and mean score of studied nurses' knowledge related to women reproductive rights pre immediately post 8 weeks' post. No statistically significant difference was found. This was disagrees with Cameron, Smith, Mercer, \& Sundstrom, (2020) who pointed out that there was a positive relation between knowledge of the studied students and their personal characteristics. This is may be due to the same belief, culture, and education of studied sample effect of knowledge of them.

Correlation between study sample knowledge and their attitude regarding reproductive rights. The finding of present study, positive correlation was found between studied sample knowledge and attitude immediately post intervention This was agree with Ajara, \& Shuaib, (2019) \& DeBeaudrap, et al., (2019) who found Positive connection between knowledge and attitude with respect to reproductive rights.

Additionally a significant improvement among studied sample attitude pre intervention compared with immediately and 8 weeks post intervention, it was surprising from the study sample, research finding highly improving among studied sample knowledge and attitude this was due to the application of educational guideline, which highly effective in improving knowledge concept and student attitude, it was immoral in Egyptian rural area to discuss issue related to sexual and reproductive health among young and married female which subsequently had dealed to several misconcept and belief related to female sexuality on their reproductive rights, so it is seriously important to conduct and repeat the study counseling program on another setting and on anther sample in Egypt, furthermore there was a highly correlation between studied sample knowledge and their attitude because improve knowledge had positively upon studied sample attitude because counseling sessions the face to face communication it effect on changing and improve knowledge and attitude. 


\section{CONCLUSION:}

In the light of the main study findings, highly improving among studied sample knowledge and attitude this was due to the application of educational guideline, which highly effective in improving knowledge concept and student attitude.

\section{RECOMMENDATIONS:}

Based on the current study findings, it can be recommended that,

- Repeat the present study educational guideline on another setting and on another sampling.

- Include male student nurse perception regarding women rights and reproductive health.

\section{REFERENCE:}

Adinew, Y. M., Worku, A. G., \& Mengesha, Z. B. (2013). Knowledge of reproductive and sexual rights among University students in Ethiopia: institution-based cross-sectional. BMC international health and human rights, 13(1), 12.

Ajara, T. A., \& Shuaib, Q. A. (2019). Knowledge and Attitude to Sexual and Reproductive Health Rights among Reproductive-Age Women (RAW) in Malete, Kwara State. Global Journal of Management And Business Research. onmental research and public health, 16(3), 417.

Askew I., Khosla R., Daniels U., Krause S., Lofthouse C., Say L., Gilmore K., and Zeid S,. (2016): Sexual and reproductive health and rights in emergencies. World Health Organ 94 (5); 311.

Bhattarai A., \& Dhakal s., (2015): Knowledge Regarding Reproductive Rights among Undergraduate Students, Scholars Journal of Applied Medical Sciences, Nepal; 3(7):2461.

Cameron, A., Smith, E., Mercer, N., \& Sundstrom, B. (2020): 'It is our duty: 'understanding parents' perspectives on reproductive and sexual health education. Sex Education, 1-17. 
Center for Disease Control and Prevention, (2014): Sexually Transmitted Disease Surveillance 2014. Atlanta: U.S. Department of Health and Human Services; 2015.pdf/icpd_and_human_rights_20_years.pdf. accessed on 14 / 6/ 2016.

DeBeaudrap, P., Mouté, C., Pasquier, E., Mac-Seing, M., Mukangwije, P. U., \& Beninguisse, G. (2019): Disability and Access to Sexual and Reproductive Health Services in Cameroon: A Mediation Analysis of the Role of Socioeconomic Factors. International journal of envier.

Eldén, L. (2019). Matrix methods in data mining and pattern recognition (Vol. 15). Siam.

Hallila, L. E., \& Al-Halabi, J. O. (2018). Saudi female university employee self-determination in their own health-related issues. Journal of Nursing Education and Practice, 8(8).

Ibrahim A., (2010): Effect of Educational Program on Adolescent Girls Regarding Reproductive Health. Unpublished doctorate Thesis. Faculty of Nursing Benha University.

Kaphle, S., Hancock, H., \& Newman, L. A. (2013). Childbirth traditions and cultural perceptions of safety in Nepal: critical spaces to ensure the survival of mothers and newborns in remote mountain villages. Midwifery, 29(10), 1173-1181.

Khosla, R., Zampas, C., Vogel, J. P., Bohren, M. A., Roseman, M., \& Erdman, J. N. (2016): International human rights and the mistreatment of women during childbirth. Health and human rights, 18(2), 131.

O'connell, C., \& Zampas, C. (2019): The human rights impact of gender stereotyping in the context of reproductive health care. International Journal of Gynecology \& Obstetrics, 144(1), 116-121.

Rajapaksa N., Piercy H., Salway S., and Samarage S., (2014): Sexual and reproductive knowledge, attitudes and behaviors in a school going population of Sri Lankan adolescents. Sexual and Reproductive Healthcare; 6(1): 3-8. 
Rashad, W., Shamekh, A., \& Ragheb, S. (2013): Assessment of women's awareness about reproductive rights. American Journal of Research Communication, 1, 65-83.

Ross, C. (2019). African American Female Adolescents' Perspectives Regarding Their Sexual and Reproductive Health Needs While in Foster Care: A Qualitative Descriptive Study (Doctoral dissertation, University of Virginia).

Shailaja, K., \& Johnson, M. E. C. (2007). Fluorides in groundwater and its impact on health. Journal of environmental biology, 28(2), 331-332.

Turshen, M. (2020). Sexual and Reproductive Health and Rights. In Women's Health Movements (pp. 191-229). Palgrave Macmillan, Singapore.

World Health Organisation, (2016): Sexual and reproductive health: Classification of female genital mutilation. Retrieved 21 February, 2016, from World Health Organization, http://www.who.int/ reproductive health/topics/fgm/overview/en.

Maleshina, A. (2020). Taking Human Reproductive Rights Seriously: The Russian Perspective. Russ. LJ, 8, 25. 
تأثير الارشادات التعليمية عن حقوق المرأة الاتجابية علي معلومات و اتجاهات طالبات التمريض

فاطمة كمال السيد عبد عشري 1, أ.م.د انعام حسن عبد العاطى² , أ.د. كاميليـا رجـب أبو شبــانهُ د. دها رمضان على2

ماجستير تمريض الامومة و النساء و التوليد كلية التمريض جامعة بورسعيد1 , كلية التريض جامعة بورسعيد²

كلية التمريض جامعة عين شمس3

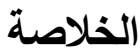

تهدف هذه الدر اسة إلى تقييم تأثير الارشادات التعليمية عن حقوق المر أة الإنجابية بين طالبات التمريض على معلوماتهن و

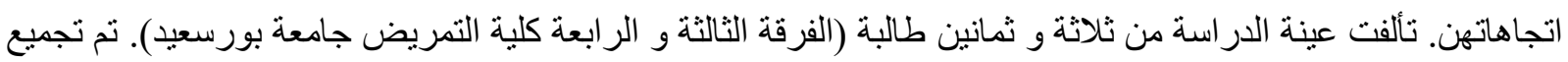
المعلومات الخاصة بالدراسة باستخدام, استمارة استبيان لمعرفة معلومات و اتجاهات الطالبات عن الصحة الانجابية. تم إعداد برنامج الارشادات التعليمية بعد مراجعة المواد العلمية. أظهرت النتائج أن جميع الطالبات ليس لديهن المستوى المرضى من المعلومات و الاتجاهات قبل تنفيذ البرنامج, أظهرت نتائج الدراسة تحسنا واضحا في معلومات و اتجاهات الطالبات بعد تنفيذ البرنامج كما أظهرت النتائج ثبات في معلومات و اتجاهات الطالبات بعد ثمانيه اسابيع من تنفيذ البرنامج وتتضمن الدارسة تحسنا ايجابيا ملحوظا في معلومات الطالبات تجاه حقوق المر اة الانجابيه بعد تنفيذ البرنامج مبانشرة وخلال

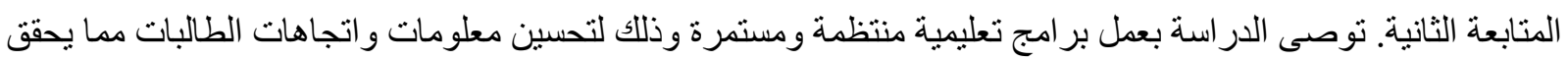
جودة عالية في الصحة الانجابية و حقوق المر أة. 